\title{
Effect of occult hepatitis B virus infection on the early-onset of hepatocellular carcinoma in patients with hepatitis $\mathbf{C}$ virus infection
}

\author{
MASAHITO NAKANO $^{1}$, TAKUMI KAWAGUCHI ${ }^{1,2}$, SHINGO NAKAMOTO $^{3}$, \\ ATSUSHI KAWAGUCHI ${ }^{4}$, TATSUO KANDA ${ }^{3}$, FUMIO IMAZEKI ${ }^{3,5}$, RYOKO KUROMATSU ${ }^{1}$, \\ SHUJI SUMIE ${ }^{1}$, MANABU SATANI ${ }^{1}$, SHINGO YAMADA ${ }^{1}$, TAKUJI TORIMURA ${ }^{1,6}$, \\ TATSUYUKI KAKUMA ${ }^{7}$, OSAMU YOKOSUKA ${ }^{3}$ and MICHIO SATA ${ }^{1,2}$ \\ ${ }^{1}$ Division of Gastroenterology, Department of Medicine, Kurume University School of Medicine; \\ ${ }^{2}$ Department of Digestive Disease Information \& Research, Kurume University School of Medicine, Kurume; \\ ${ }^{3}$ Department of Gastroenterology and Nephrology, Graduate School of Medicine, Chiba University, Chiba; \\ ${ }^{4}$ Biostatistics Center, Kurume University, Kurume; ${ }^{5}$ Safety and Health Organization, Chiba University, Chiba; \\ ${ }^{6}$ Liver Cancer Research Division, Research Center for Innovative Cancer Therapy, Kurume University; \\ ${ }^{7}$ Department of Biostatistics, Kurume University Graduate School of Medicine, Kurume, Japan
}

Received June 22, 2013; Accepted August 2, 2013

DOI: $10.3892 /$ or.2013.2700

\begin{abstract}
Although overt hepatitis B virus (HBV) infection promotes the onset of hepatocellular carcinoma (HCC) in hepatitis $\mathrm{C}$ virus (HCV)-infected patients, the effect of occult HBV infection remains unclear. The aim of this study was to investigate the effect of occult HBV infection on the early-onset of $\mathrm{HCC}$ in $\mathrm{HCV}$-infected patients. A total of 173 HCC patients with HCV infection were enrolled and classified into 2 groups according to the median age of HCC onset: the early-onset group $(n=91 ; 61.1 \pm 5.6$ years) and the late-onset group ( $\mathrm{n}=82 ; 73.8 \pm 3.7$ years). Independent factors associated with the early-onset of HCC were assessed by multivariate analysis. In the overall analysis, independent risk factors for the early-onset of HCC were the white blood cell count and
\end{abstract}

Correspondence to: Dr Takumi Kawaguchi, Division of Gastroenterology, Department of Medicine, Kurume University School of Medicine, 67 Asahi-machi, Kurume 830-0011, Japan

E-mail: takumi@med.kurume-u.ac.jp

Abbreviations: $\mathrm{HCC}$, hepatocellular carcinoma; $\mathrm{HCV}$, hepatitis $\mathrm{C}$ virus; HBV, hepatitis B virus; HBsAg, hepatitis B surface antigen; BMI, body mass index; WBC, white blood cell; HbAlc, hemoglobin A1c; AST, aspartate aminotransferase; ALT; alanine aminotransferase; AFP, $\alpha$-fetoprotein; DCP, des- $\gamma$-carboxy prothrombin; HOMA, homeostasis model assessment; APRI, AST to platelet ratio index; AUROC, area under the receiver operating characteristic curve analysis; MAPK, mitogen activated protein kinase

Key words: latent $\mathrm{HBV}$ infection, hepatoma, liver cancer, oncogenesis, white blood cell alanine aminotransferase level, but not the presence of HBV DNA. In a stratification analysis according to albumin levels of $\geq 3.5 \mathrm{~g} / \mathrm{dl}$, the presence of HBV DNA was a significant independent risk factor for the early-onset of HCC (OR 145.18, 95\% CI 1.38-15296.61, $\mathrm{P}=0.036$ ), whereas the presence of antibodies against hepatitis B core antigen was not found to be a risk factor. The presence of HBV DNA was not a risk factor for the early-onset of HCC in the overall analysis. However, its presence was an independent factor for the early-onset of HCC in HCV-infected patients with an albumin level of $\geq 3.5 \mathrm{~g} / \mathrm{dl}$. Thus, occult HBV infection may accelerate hepatocarcinogenesis in $\mathrm{HCV}$-infected patients with relatively low carcinogenic potential.

\section{Introduction}

Hepatocellular carcinoma (HCC) is one of the most common malignancies worldwide. It ranks third in men and fifth in women as the cause of death from malignancies in Japan (1). Chronic hepatitis $\mathrm{C}$ virus (HCV) infection is the major cause of HCC and accounts for $\sim 60-70 \%$ of HCC cases in Japan (2). In addition to hepatic inflammation and subsequent fibrosis, various other factors including aging, obesity and diabetes mellitus are involved in the hepatocarcinogenesis in HCV-infected patients (3-5).

Co-infection of HCV with hepatitis B virus (HBV) is thought to synergistically increase the development of HCC (6). The status of HBV infection is evaluated by the presence of hepatitis B surface antigen (HBsAg), antibodies against hepatitis B core antigen ( $\mathrm{HBcAb}$ ), and HBV DNA. In some cases, HBV DNA can be detected in the serum or liver tissue of patients who are negative for $\mathrm{HBsAg}$, a condition referred to as 'occult HBV infection' $(7,8)$. In Japan, the prevalence of occult HBV infection in HCV-infected patients is reported 
Table I. Nucleotide positions and sequences of TaqMan PCR primers and probes.

\begin{tabular}{llc}
\hline Primer/Probe & \multicolumn{1}{c}{ Sequence } & Position \\
\hline S-sense & TGTACAAAACCTTCGGACGGAAA & $442-464$ \\
S-antisense & TGCGAAAGCCCAGGATGATG & $485-504$ \\
S-probe & CTGCACTTGTATTCCC & $465-480$ \\
C-sense & ACTGTGGTTTCACATTTCCTGTCTT & $2072-2096$ \\
C-antisense & GGCATTTGGTGGTCTGTAAGC & $2163-2183$ \\
C-probe & CCACACTCCAAAAGAC & $2132-2147$ \\
X-sense & CTACTGTTCAAGCCTCCAAGCT & $1729-1750$ \\
X-antisense & GCTCCAAATTCTTTATACGGGTCAATG & $1778-1804$ \\
X-probe & AAGCCACCCAAGGCAC & $1751-1766$ \\
\hline
\end{tabular}

Nucleotide positions are based on the sequence of hepatitis B virus subtype adr4 (GenBank accession no. X01587) (29).

to be between $37.7 \%$ and $90 \%$ (9-11). Occult HBV infection is associated with a poor response to interferon therapy for chronic hepatitis $\mathrm{C}(12,13)$ and is also known to accelerate the progression of liver fibrosis, resulting in cirrhosis in patients with HCV infection $(9,14,15)$. Several previous studies have examined the impact of occult HBV infection on the development of HCC in HCV-infected patients, but no clear conclusions have emerged $(14,16,17)$. Moreover, the effects of occult HBV infection on the early-onset of HCC have not been investigated in $\mathrm{HCV}$-infected patients.

Albumin is produced by hepatocytes, and the level of serum albumin is used to evaluate hepatic function (18). Albumin plays a significant role in maintaining colloid osmotic pressure and transports drugs and endogenous substances including bilirubin and unesterified free fatty acids (19). In addition, albumin exerts antioxidative properties (19), and hypoalbuminemia has been shown to be an independent risk factor for mortality among residents of a hyperendemic area of HCV infection in Japan (20). A serum albumin level of $\geq 3.5 \mathrm{~g} / \mathrm{dl}$ is an independent predictor of survival in HCC patients $(21,22)$ and in cirrhotic patients with a serum albumin levels of $<3.5 \mathrm{~g} / \mathrm{dl}$, branched-chain amino acids increase serum albumin levels and subsequently suppress hepatocarcinogenesis $(23,24)$. Thus, the serum albumin level is an important factor in hepatocarcinogenesis.

The aim of this study is to investigate the impact of occult $\mathrm{HBV}$ infection on the early-onset of HCC in HCV-infected patients. We also performed a stratification analysis according to the serum albumin level.

\section{Subjects and methods}

Subjects. We conducted a retrospective study to investigate the effect of the presence of HBV DNA on the early-onset of HCC in HCV-infected patients. Between 1995 and 2011, 325 patients underwent hepatic resection at the Kurume University Hospital. The inclusion criteria were histologically proven $\mathrm{HCC}$, a positive result for serum anti-HCV, and a negative result for serum HBsAg. Exclusion criteria were the presence of autoimmune hepatitis, primary biliary cirrhosis, and hemochromatosis, no test results for serum HBV DNA, and a histological diagnosis of combined hepatocellular and cholangiocellular carcinoma. Although 214 patients met the inclusion criteria, 41 patients had to be excluded because of one or more of these reasons. The remaining $173 \mathrm{HCC}$ patients with $\mathrm{HCV}$ infection were therefore enrolled in this study and classified into 2 groups according to the median age of HCC onset: the early-onset group $(\mathrm{n}=91 ; 61.1 \pm 5.6$ years $)$ and the late-onset group ( $n=82 ; 73.8 \pm 3.7$ years).

The study protocol was approved by the institutional review board, and informed consent for participation in the study was obtained from each subject. None of the subjects were institutionalized.

Data collection. Demographic data were collected at the time of hepatic resection including age, gender, and alcohol intake. Body mass index (BMI) was calculated as body weight in kilograms divided by the square of height in meters $\left(\mathrm{kg} / \mathrm{m}^{2}\right)$.

Venous blood samples were taken in the morning after a 12-h overnight fast. The presence of serum anti-HCV, HBsAg, and $\mathrm{HBcAb}$ was tested using standard clinical methods (Department of Clinical Laboratory, Kurume University Hospital). Blood platelet count, white blood cell (WBC) count, prothrombin time \%, plasma glucose levels; hemoglobin Alc (HbA1c) levels, and serum levels of aspartate aminotransferase (AST), alanine aminotransferase (ALT), albumin, total bilirubin, insulin, $\alpha$-fetoprotein (AFP), and des- $\gamma$-carboxy prothrombin (DCP) were also measured using standard clinical methods. Insulin resistance was evaluated on the basis of fasting levels of plasma glucose and insulin, according to the homeostasis model assessment for insulin resistance (HOMAIR), as previously described (25).

The stage of hepatic fibrosis was assessed using the AST-to-platelet ratio index (APRI), which is calculated as the serum AST level (U/l)/upper limit of normal AST (U/l) $\mathrm{x} 100 /$ platelet count $\left(\mathrm{x} 10^{4} / \mathrm{ml}\right)$. Patients with APRI values of $\leq 1.5$ were diagnosed as having chronic hepatitis, and patients with APRI values $>1.5$ were diagnosed as having liver cirrhosis, as previously described (26). The degree of liver cirrhosis was categorized according to the Child-Pugh classification (27). Diabetes mellitus was diagnosed on the basis of fasting blood glucose levels $>126 \mathrm{mg} / \mathrm{dl}$ or HbAlc levels $>6.5 \%$, in accordance with the Diagnostic Criteria for 
Table II. Differences in the clinical characteristics between the early-onset and late-onset groups.

\begin{tabular}{|c|c|c|c|c|}
\hline Variable & Reference value & Early-onset & Late-onset & $\mathrm{P}$ \\
\hline Number of patients & & 91 & 82 & \\
\hline Age (years) & & $61.1 \pm 5.6$ & $73.8 \pm 3.7$ & $<0.001$ \\
\hline $\operatorname{AFP}(\mathrm{ng} / \mathrm{ml})$ & $<8.7$ & $1876 \pm 12163$ & $769 \pm 3246$ & 0.588 \\
\hline $\mathrm{DCP}(\mathrm{mAU} / \mathrm{ml})$ & $<40$ & $1083 \pm 4120$ & $1071 \pm 3845$ & 0.378 \\
\hline Maximal HCC size (mm) & N/A & $30.4 \pm 19.6$ & $33.2 \pm 16.2$ & 0.055 \\
\hline Gender (female/male) & N/A & $23 / 68$ & $20 / 62$ & 0.893 \\
\hline BMI $\left(\mathrm{kg} / \mathrm{m}^{2}\right)$ & $18.5-22.0$ & $23.6 \pm 3.6$ & $22.4 \pm 3.2$ & 0.045 \\
\hline Daily alcohol intake (none/0-60 g/>60 g) & N/A & $21 / 42 / 14$ & $23 / 36 / 10$ & 0.676 \\
\hline Platelet count $\left(\times 10^{4} / \mathrm{mm}^{3}\right)$ & $13-36$ & $13.8 \pm 5.4$ & $13.5 \pm 4.6$ & 0.988 \\
\hline WBC count $\left(/ \mathrm{mm}^{3}\right)$ & $4000-9000$ & $5009 \pm 1526$ & $4420 \pm 1210$ & 0.012 \\
\hline $\operatorname{AST}(\mathrm{U} / \mathrm{l})$ & $13-33$ & $56.2 \pm 29.5$ & $52.8 \pm 27.2$ & 0.412 \\
\hline ALT (U/l) & $6-30$ & $62.2 \pm 40.9$ & $51.7 \pm 31.7$ & 0.104 \\
\hline Albumin (g/dl) & $4.0-5.0$ & $3.87 \pm 0.45$ & $3.85 \pm 0.38$ & 0.520 \\
\hline Prothrombin time $(\%)$ & $70-130$ & $90.0 \pm 11.2$ & $91.7 \pm 12.2$ & 0.272 \\
\hline Total bilirubin (mg/dl) & $0.3-1.2$ & $0.84 \pm 0.35$ & $0.79 \pm 0.29$ & 0.346 \\
\hline Chronic hepatitis/Child-Pugh class A/Child-Pugh class B & $\mathrm{N} / \mathrm{A}$ & $40 / 49 / 2$ & $36 / 44 / 2$ & 0.994 \\
\hline Complication of diabetes mellitus (yes/no) & N/A & $30 / 61$ & $20 / 62$ & 0.214 \\
\hline Fasting blood glucose (mg/dl) & 80-109 & $119 \pm 39$ & $107 \pm 31$ & 0.060 \\
\hline Insulin $(\mu \mathrm{U} / \mathrm{ml})$ & $5-20$ & $13.1 \pm 10.4$ & $9.8 \pm 8.0$ & 0.014 \\
\hline HOMA-IR & $<2.5$ & $3.05 \pm 2.47$ & $2.11 \pm 1.03$ & 0.622 \\
\hline HbA1c $(\%)$ & $4.6-6.2$ & $5.77 \pm 0.88$ & $5.50 \pm 0.78$ & 0.053 \\
\hline $\mathrm{HBcAb}$ positive/negative & N/A & $49 / 42$ & $50 / 32$ & 0.344 \\
\hline HBV DNA positive/negative & N/A & $6 / 85$ & $3 / 79$ & 0.385 \\
\hline
\end{tabular}

Values are expressed as the mean \pm SE. AFP, $\alpha$-fetoprotein; DCP, des- $\gamma$-carboxy prothrombin; HCC, hepatocellular carcinoma; BMI, body mass index; WBC, white blood cell; AST, aspartate aminotransferase; ALT, alanine aminotransferase; HOMA-IR, homeostasis model assessment for insulin resistance; HbA1c, hemoglobin A1c; HBcAb, antibody for hepatitis B core antigen; HBV, hepatitis B virus; N/A, not applicable.

Diabetes Mellitus of the Japan Diabetes Society (28), or the use of antidiabetic agents.

Nucleic acid extraction from serum. Total nucleic acid was extracted from $300 \mu \mathrm{l}$ of plasma using a commercially available kit (High Pure Viral Nucleic Acid kit; Roche Diagnostics, Tokyo, Japan) according to the manufacturer's instructions. The extracted nucleic acid was eluted in $25 \mu \mathrm{l}$ of elution buffer.

PCR for $H B V D N A$. Serum HBV DNA was analyzed for the presence of $\mathrm{HBs}, \mathrm{HBc}$, and $\mathrm{HBx}(\mathrm{S}, \mathrm{C}$ and $\mathrm{X}$ ) regions using TaqMan real-time PCR according to the manufacturer's instructions (TaqMan Fast Universal PCR Master mix; Applied Biosystems, Tokyo, Japan). The oligonucleotide primers and probes that were optimized for the HBV subtype $\operatorname{adr} 4$ (29) were specific for the $\mathrm{S}, \mathrm{X}$ and $\mathrm{C}$ region sequences are listed in Table I. The full-length HBV DNA (GenBank accession no. X01587) (29) was used as an internal standard in the quantitative real-time detection PCR. We used $8 \mu \mathrm{l}$ of nucleic acid-containing serum in our study for better sensitivity. The limit of sensitivity of our TaqMan Real-time PCR methods was 4.5 copies/well, and the detection limit of our tests was 45 copies/ml (1.7 log copies/ml). A real-time PCR assay (COBAS TaqMan HBV Auto; Roche Diagnostics) was also performed to detect the core region of HBV DNA (limit of quantification, $1.8 \mathrm{log}$ copies/ml). The presence of $\mathrm{HBV}$ DNA was defined as any positivity of $\mathrm{S}, \mathrm{X}$ or $\mathrm{C}$ region.

Statistical analysis. Data are expressed as the absolute value or the mean \pm SD. Differences between the early-onset and late-onset groups were analyzed using the Mann-Whitney U test. A logistic regression model with the Firth's correction 30 was used for multivariate stepwise analysis to identify independent variables associated with the early-onset of HCC, as previously described $(31,32)$. All P-values were 2-tailed, and a level of $<0.05$ was considered statistically significant. All statistical analyses were conducted using SAS version 9.2 (SAS Institute, Cary, NC, USA) or R packages version 2.15.2 (URL http://www.R-project.org/).

\section{Results}

Univariate analysis between the early-onset and late-onset groups. AFP levels, DCP levels, and maximal HCC size did not differ between the early-onset and late-onset groups (Table II). Furthermore, although BMI, WBC count, and serum insulin levels were significantly higher in the early-onset group than in the late-onset group, there were no significant differences 
Table III. Multivariate stepwise analysis for factors associated with the early-onset of hepatocellular carcinoma.

\begin{tabular}{lrccc}
\hline & Unit & Odds ratio & $95 \%$ CI & P \\
\hline HbA1c & 1 & 1.37 & $0.91-2.07$ & 0.136 \\
BMI & 1 & 1.08 & $0.98-1.19$ & 0.133 \\
ALT & 10 & 1.10 & $1.00-1.21$ & 0.045 \\
DCP & 20 & 0.99 & $0.98-1.00$ & 0.091 \\
WBC count & 1000 & 1.35 & $1.06-1.73$ & 0.014
\end{tabular}

All P-values were 2-tailed, and a level of $<0.05$ was considered statistically significant. HbA1c, hemoglobin A1c; BMI, body mass index; ALT, alanine aminotransferase; DCP, des- $\gamma$-carboxy prothrombin; WBC, white blood cell.

in the daily alcohol intake, platelet count, prothrombin time, Child-Pugh classification, presence of diabetes mellitus as a comorbidity, fasting blood glucose level, HOMA-IR value, HbA1c levels, and the serum levels of AST, ALT, albumin, and total bilirubin (Table II). The presence of HBcAb and HBV DNA did not differ either between the early-onset and lateonset groups (Table II).

Multivariate stepwise analysis for early-onset of HCC. Multivariate stepwise analysis showed that the serum ALT level and WBC count were independent risk factors for the early-onset of HCC (OR 1.10; 95\% CI 1.00-1.21; $\mathrm{P}=0.045$ and OR 1.35; 95\% CI 1.06-1.73; $\mathrm{P}=0.014$, respectively; Table III), but not the presence of $\mathrm{HBcAb}$ or HBV DNA.

Stratification analysis according to serum albumin level. Differences in the clinical characteristics between patients with the albumin level of $\geq 3.5 \mathrm{~g} / \mathrm{dl}$ and $<3.5 \mathrm{~g} / \mathrm{dl}$ were summarized in Table IV. There were no significant differences in AFP levels, DCP levels, and maximal HCC size between the albumin level of $\geq 3.5 \mathrm{~g} / \mathrm{dl}$ and $<3.5 \mathrm{~g} / \mathrm{dl}$ groups (Table IV). In the albumin level of $\geq 3.5 \mathrm{~g} / \mathrm{dl}$ group, a significant elevation was seen in platelet count, prothrombin time and the number of patients with chronic hepatitis and a significant depletion was seen in AST level than in the albumin level of $<3.5 \mathrm{~g} /$ dl group. However, other biochemical parameters and the

Table IV. Differences in the clinical characteristics between patients with the albumin level of $\geq 3.5 \mathrm{~g} / \mathrm{dl}$ and $<3.5 \mathrm{~g} / \mathrm{dl}$.

\begin{tabular}{|c|c|c|c|c|}
\hline \multirow[b]{2}{*}{ Variable } & \multirow[b]{2}{*}{ Reference value } & \multicolumn{2}{|c|}{ Albumin level of } & \multirow[b]{2}{*}{$\mathrm{P}$} \\
\hline & & $\geq 3.5 \mathrm{~g} / \mathrm{dl}$ & $<3.5 \mathrm{~g} / \mathrm{dl}$ & \\
\hline Number of patients & & 138 & 35 & \\
\hline Age (years) & & $67.8 \pm 8.1$ & $67.9 \pm 6.7$ & 0.895 \\
\hline $\operatorname{AFP}(\mathrm{ng} / \mathrm{ml})$ & $<8.7$ & $786 \pm 3219$ & $3262 \pm 18195$ & 0.248 \\
\hline $\mathrm{DCP}(\mathrm{mAU} / \mathrm{ml})$ & $<40$ & $854 \pm 3269$ & $1961 \pm 5977$ & 0.306 \\
\hline Maximal HCC size (mm) & $\mathrm{N} / \mathrm{A}$ & $30.6 \pm 15.9$ & $36.8 \pm 23.8$ & 0.171 \\
\hline Gender (female/male) & $\mathrm{N} / \mathrm{A}$ & $35 / 103$ & $8 / 27$ & 0.759 \\
\hline BMI $\left(\mathrm{kg} / \mathrm{m}^{2}\right)$ & $18.5-22.0$ & $23.0 \pm 3.5$ & $23.0 \pm 3.4$ & 0.918 \\
\hline Daily alcohol intake (none/0-60 g/>60 g) & N/A & $21 / 58 / 38$ & $3 / 20 / 6$ & 0.172 \\
\hline Platelet count $\left(\times 10^{4} / \mathrm{mm}^{3}\right)$ & $13-36$ & $14.3 \pm 4.9$ & $11.3 \pm 4.8$ & 0.001 \\
\hline WBC count $\left(/ \mathrm{mm}^{3}\right)$ & $4000-9000$ & $4798 \pm 1395$ & $4291 \pm 1331$ & 0.052 \\
\hline $\operatorname{AST}(\mathrm{U} / \mathrm{l})$ & $13-33$ & $51.2 \pm 26.2$ & $67.1 \pm 32.6$ & 0.001 \\
\hline $\operatorname{ALT}(\mathrm{U} / \mathrm{l})$ & $6-30$ & $54.9 \pm 37.4$ & $63.4 \pm 32.7$ & 0.057 \\
\hline Albumin $(\mathrm{g} / \mathrm{dl})$ & $4.0-5.0$ & $4.02 \pm 0.28$ & $3.23 \pm 0.20$ & $<0.001$ \\
\hline Prothrombin time $(\%)$ & $70-130$ & $91.6 \pm 12.0$ & $88.0 \pm 10.0$ & 0.038 \\
\hline Total bilirubin (mg/dl) & $0.3-1.2$ & $0.82 \pm 0.34$ & $0.80 \pm 0.28$ & 0.822 \\
\hline Chronic hepatitis/Child-Pugh class A/Child-Pugh class B & N/A & $69 / 69 / 0$ & $7 / 24 / 4$ & $<0.001$ \\
\hline Complication of diabetes mellitus (yes/no) & N/A & $38 / 100$ & $12 / 23$ & 0.431 \\
\hline Fasting blood glucose (mg/dl) & 80-109 & $112 \pm 37$ & $121 \pm 49$ & 0.694 \\
\hline Insulin $(\mu \mathrm{U} / \mathrm{ml})$ & $5-20$ & $10.1 \pm 6.4$ & $17.6 \pm 16.3$ & 0.063 \\
\hline HOMA-IR & $<2.5$ & $3.12 \pm 3.87$ & $4.23 \pm 2.23$ & 0.315 \\
\hline $\operatorname{HbA1c}(\%)$ & $4.6-6.2$ & $5.61 \pm 0.79$ & $5.68 \pm 1.04$ & 0.905 \\
\hline $\mathrm{HBcAb}$ positive/negative & N/A & $75 / 63$ & $24 / 11$ & 0.129 \\
\hline HBV DNA positive/negative & $\mathrm{N} / \mathrm{A}$ & $6 / 132$ & $3 / 32$ & 0.315 \\
\hline
\end{tabular}

Values are expressed as the mean \pm SE. AFP, $\alpha$-fetoprotein; DCP, des- $\gamma$-carboxy prothrombin; HCC, hepatocellular carcinoma; BMI, body mass index; WBC, white blood cell; AST, aspartate aminotransferase; ALT, alanine aminotransferase; HOMA-IR, homeostasis model assessment for insulin resistance; HbA1c, hemoglobin A1c; HBcAb, antibody for hepatitis B core antigen; HBV, hepatitis B virus; N/A, not applicable. 
Table V. Multivariate stepwise analysis for factors associated with the early-onset of hepatocellular carcinoma in patients with a serum albumin level of $\geq 3.5 \mathrm{~g} / \mathrm{dl}$.

\begin{tabular}{lcccc}
\hline & Unit & Odds ratio & 95\% CI \\
\hline HBcAb & Positive & 0.59 & $0.27-1.26$ & 0.169 \\
HBV DNA & Positive & 145.18 & $1.38-15296.61$ & 0.036 \\
Prothrombin time & 10 & 0.76 & $0.54-1.08$ & 0.109 \\
ALT & 10 & 1.08 & $0.97-1.21$ & 0.145 \\
Albumin & 0.1 & 1.17 & $0.01-1.36$ & 0.036 \\
DCP & 20 & 0.99 & $0.84-1.00$ & 0.107 \\
Platelet count & 1 & 0.92 & $1.15-2.35$ & 0.006 \\
WBC count & 1000 & 1.64 & & \\
\hline
\end{tabular}

All P-values were 2-tailed, and a level of $<0.05$ was considered statistically significant. HBcAb, antibody for hepatitis B core antigen; HBV, hepatitis B virus; ALT, alanine aminotransferase; DCP, des- $\gamma$-carboxy prothrombin; WBC, white blood cell.

Table VI. Multivariate stepwise analysis for factors associated with the early-onset of hepatocellular carcinoma in patients with a serum albumin level of $<3.5 \mathrm{~g} / \mathrm{dl}$.

\begin{tabular}{lcccc}
\hline & Unit & Odds ratio & $95 \%$ CI & P \\
\hline HbA1c & 1 & 1.83 & $0.75-4.47$ & 0.183 \\
HBV DNA & Positive & 0.00 & $0.00-2.96$ & 0.093 \\
AFP & 20 & 1.39 & $1.01-1.93$ & 0.045 \\
\hline
\end{tabular}

All P-values were 2-tailed, and a level of $<0.05$ was considered statistically significant. HbA1c, hemoglobin A1c; HBV, hepatitis B virus; AFP, $\alpha$-fetoprotein.

presence of $\mathrm{HBcAb}$ and HBV DNA did not differ between the albumin level of $\geq 3.5 \mathrm{~g} / \mathrm{dl}$ and $<3.5 \mathrm{~g} / \mathrm{dl}$ groups (Table IV).

In patients with a serum albumin level of $\geq 3.5 \mathrm{~g} / \mathrm{dl}$, the WBC count and serum levels of albumin and DCP were identified as independent factors associated with the early-onset of HCC (OR 1.64; 95\% CI 1.15-2.35; P=0.006, OR 1.17; 95\% CI 1.01-1.36; $\mathrm{P}=0.036$, and OR 0.99; 95\% CI 0.98-1.00; $\mathrm{P}=0.037$, respectively; Table $\mathrm{V}$ ). Although the presence of $\mathrm{HBcAb}$ was not found to be a significant risk factor for the early-onset of HCC, the presence of HBV DNA was identified as a significant independent risk factor associated with the early-onset of HCC (OR 145.18; 95\% CI 1.38-15296.61; $\mathrm{P}=0.036$; Table VI).

In patients with a serum albumin level of $<3.5 \mathrm{~g} / \mathrm{dl}$, the serum AFP level was the only significant risk factor found to be associated with the early-onset of HCC (Table V). The presence of $\mathrm{HBcAb}$ and $\mathrm{HBV}$ DNA was not found to be a significant risk factor for the early-onset of HCC.

\section{Discussion}

In the overall analysis, the presence of HBV DNA in serum was not identified as a risk factor for the early-onset of HCC in $\mathrm{HCV}$-infected patients. However, a stratification analysis according to a serum albumin level of $\geq 3.5 \mathrm{~g} / \mathrm{dl}$ revealed that the presence of HBV DNA was an independent factor for the early-onset of HCC. These findings suggest that occult HBV infection may accelerate hepatocarcinogenesis in $\mathrm{HCV}$-infected patients with a relatively low carcinogenic potential.

Although co-infection of $\mathrm{HCV}$ and $\mathrm{HBV}$ is thought to synergistically increase the risk of HCC (6), the overall analysis in this study showed that occult HBV infection was not significantly associated with the early-onset of HCC in HCV-infected patients. Similarly, several studies conducted in Asia have also failed to show any significant effect of occult HBV infection in these patients (33-35). Recently, Lok et al (36) performed a nested case-control study using a large number of patients enrolled in the HALT-C cohort and reported no significant difference in the prevalence of occult HBV infection between HCC and non-HCC patients with HCV infection. Taken together, these results suggest that occult HBV infection may not be an intensive promoter of $\mathrm{HCC}$ development in the presence of a potent carcinogenic factor such as HCV infection.

In contrast with these previous studies and with our own findings for all patients, a stratification analysis according to a serum albumin level of $\geq 3.5 \mathrm{~g} / \mathrm{dl}$ showed that occult HBV infection was an independent risk factor for the early-onset of HCC. In patients with occult $\mathrm{HBV}$ infection, it is unclear whether a presence of HBV DNA is due to full-length HBV DNA replicated from covalently closed circular DNA in hepatocytes or fragmented HBV DNA integrated into the hepatocyte genome. However, the $H B x$ gene is frequently integrated into cellular genes in HCC (37). The HBx protein upregulates the expression of proto-oncogenes including $c$-jun, $c$-fos and $c$-myc, all of which can promote hepatocarcinogenesis $(38,39)$. In addition, albumin plays a crucial role in the development of various diseases, as it is a major antioxidant (19). In cirrhotic patients with a serum albumin level of $<3.5 \mathrm{~g} / \mathrm{dl}$, branched-chain amino acids increase serum albumin levels, and this subsequently suppresses hepatocarcinogenesis $(23,24)$. In this study, we found a significant association between occult HBV infection and the early-onset of HCC in patients with a serum albumin level of $\geq 3.5 \mathrm{~g} / \mathrm{dl}$, but not in patients with a serum albumin level of $<3.5 \mathrm{~g} / \mathrm{dl}$. Taken together, these findings suggest that HBV DNA may promote hepatocarcinogenesis in HCV-infected patients with relatively low carcinogenic potential. 
Although we designed this study to investigate the effect of HBV DNA on the early-onset of $\mathrm{HCC}$ in $\mathrm{HCV}$-infected patients, we found instead that an elevated WBC count is an independent risk factor for the early-onset of HCC in HCV-infected patients. An elevated WBC count may reflect the consequences or underlying pathogenesis of the early-onset of $\mathrm{HCC}$. One possible explanation is aging, because the WBC count declines in old age (40). Alternatively, an elevated WBC count still within the reference range is known to be associated with the development of various malignancies including gastric, colorectal, endometrial and lung cancers $(41,42)$. The WBC count is a well-validated biomarker of inflammation. Chronic inflammation is a possible risk factor for hepatocarcinogenesis as it leads to the activation of receptors for chemokine and advanced glycation-end products $(43,44)$. Another inflammation marker, C-reactive protein, is reported to be a diagnostic and prognostic marker of HCC $(45,46)$. Taken together, these findings suggest that inflammation may promote the earlyonset of $\mathrm{HCC}$ in $\mathrm{HCV}$-infected patients.

A limitation of this study is that there were only a small number of HBV DNA-positive patients. Previous studies regarding occult HBV infection had a similar limitation $(33,47,48)$. Since occult HBV infection is not frequently seen in HCV-infected patients with HCC, a multicenter study is needed to confirm our findings.

In conclusion, the presence of HBV DNA in serum was not a risk factor for the early-onset of HCC in HCV-infected patients. However, a stratification analysis based on a serum albumin level of $\geq 3.5 \mathrm{~g} / \mathrm{dl}$ revealed that presence of HBV DNA in serum was an independent risk factor for the early-onset of HCC. These findings suggest that occult HBV infection may accelerate hepatocarcinogenesis in HCV-infected patients with relatively low carcinogenic potential.

\section{Acknowledgements}

This study was supported, in part, by Health and Labour Sciences Research Grants for Research on Hepatitis from the Ministry of Health, Labour and Welfare of Japan.

\section{References}

1. Kiyosawa K, Umemura T, Ichijo T, et al: Hepatocellular carcinoma: recent trends in Japan. Gastroenterology 127: S17-S26, 2004

2. Taura N, Fukushima N, Yastuhashi H, et al: The incidence of hepatocellular carcinoma associated with hepatitis $\mathrm{C}$ infection decreased in Kyushu area. Med Sci Monit 17: PH7-PH11, 2011.

3. Koike K: Hepatitis $\mathrm{C}$ as a metabolic disease: implication for the pathogenesis of NASH. Hepatol Res 33: 145-150, 2005.

4. Kawaguchi $T$ and Sata M: Importance of hepatitis C virusassociated insulin resistance: therapeutic strategies for insulin sensitization. World J Gastroenterol 16: 1943-52, 2010.

5. Sumie S, Kawaguchi T, Kuromatsu R, et al: Total and high molecular weight adiponectin and hepatocellular carcinoma with HCV infection. PLoS One 6: e26840, 2011.

6. Wu Q and Liu Q: Do hepatitis B virus and hepatitis C virus co-infections increase hepatocellular carcinoma occurrence through synergistically modulating lipogenic gene expression? Hepatol Res 42: 733-740, 2012.

7. Torbenson M and Thomas DL: Occult hepatitis B. Lancet Infect Dis 2: 479-486, 2002.

8. Blackard JT, Martin CM, Sengupta S and Forrester J: Limited infection with occult hepatitis B virus in drug users in the USA. Hepatol Res 43: 413-417, 2013.
9. Koike K, Kobayashi M, Gondo M, Hayashi I, Osuga T and Takada S: Hepatitis B virus DNA is frequently found in liver biopsy samples from hepatitis $\mathrm{C}$ virus-infected chronic hepatitis patients. J Med Virol 54: 249-255, 1998.

10. Fukuda R, Ishimura N, Niigaki M, et al: Serologically silent hepatitis B virus coinfection in patients with hepatitis C virus-associated chronic liver disease: clinical and virological significance. J Med Virol 58: 201-207, 1999.

11. Nirei K, Kaneko M, Moriyama M and Arakawa Y: The clinical features of chronic hepatitis $C$ are not affected by the coexistence of hepatitis B virus DNA in patients negative for hepatitis B surface antigen. Intervirology 43: 95-101, 2000.

12. Mrani S, Chemin I, Menouar K, et al: Occult HBV infection may represent a major risk factor of non-response to antiviral therapy of chronic hepatitis C. J Med Virol 79: 1075-1081, 2007

13. Berberova M, Mendizova A, Popchristova E, Krastev N and Genov J: Disease and treatment outcome in chronic active hepatitis $\mathrm{C}$ with occult HBV infection. Hepatogastroenterology 50: 2009-2012, 2003.

14. Squadrito G, Pollicino T, Cacciola I, et al: Occult hepatitis B virus infection is associated with the development of hepatocellular carcinoma in chronic hepatitis $\mathrm{C}$ patients. Cancer 106: 1326-1330, 2006.

15. Cacciola I, Pollicino T, Squadrito G, Cerenzia G, Orlando ME and Raimondo G: Occult hepatitis B virus infection in patients with chronic hepatitis C liver disease. N Engl J Med 341: 22-26, 1999.

16. Hasegawa I, Orito E, Tanaka Y, et al: Impact of occult hepatitis B virus infection on efficacy and prognosis of interferon-alpha therapy for patients with chronic hepatitis C. Liver Int 25: 247-253, 2005

17. Ikeda K, Marusawa H, Osaki Y, et al: Antibody to hepatitis B core antigen and risk for hepatitis $\mathrm{C}$-related hepatocellular carcinoma: a prospective study. Ann Intern Med 146: 649-656, 2007.

18. Kawaguchi T,Izumi N, Charlton MR and Sata M: Branched-chain amino acids as pharmacological nutrients in chronic liver disease. Hepatology 54: 1063-1070, 2011.

19. Sakata M, Kawaguchi T, Taniguchi E, Abe M, Koga H and Sata M: Quick and simple method for increasing the reduced albumin fraction in human serum albumin preparations by using stronger neo-minophagen C. Hepatol Res 41: 1120-1125, 2011.

20. Nagao Y and Sata M: Serum albumin and mortality risk in a hyperendemic area of HCV infection in Japan. Virol J 7: 375, 2010.

21. Pacella CM, Francica G, Di Lascio FM, et al: Long-term outcome of cirrhotic patients with early hepatocellular carcinoma treated with ultrasound-guided percutaneous laser ablation: a retrospective analysis. J Clin Oncol 27: 2615-2621, 2009.

22. Nishikawa $\mathrm{H}$, Osaki $\mathrm{Y}$, Iguchi $\mathrm{E}$, et al: Radiofrequency ablation for hepatocellular carcinoma: the relationship between a new grading system for the ablative margin and clinical outcomes. J Gastroenterol 48: 951-965, 2013.

23. Muto Y, Sato S, Watanabe A, et al: Effects of oral branchedchain amino acid granules on event-free survival in patients with liver cirrhosis. Clin Gastroenterol Hepatol 3: 705-713, 2005.

24. Muto Y, Sato S, Watanabe A, et al: Overweight and obesity increase the risk for liver cancer in patients with liver cirrhosis and long-term oral supplementation with branched-chain amino acid granules inhibits liver carcinogenesis in heavier patients with liver cirrhosis. Hepatol Res 35: 204-214, 2006.

25. Kawaguchi T, Yoshida T, Harada M, et al: Hepatitis C virus down-regulates insulin receptor substrates 1 and 2 through up-regulation of suppressor of cytokine signaling 3. Am J Pathol 165: 1499-1508, 2004

26. Itou M, Kawaguchi T, Taniguchi E, et al: Altered expression of glucagon-like peptide-1 and dipeptidyl peptidase IV in patients with HCV-related glucose intolerance. J Gastroenterol Hepatol 23: 244-251, 2008

27. Pascal JP and Cales P: Propranolol in the prevention of first upper gastrointestinal tract hemorrhage in patients with cirrhosis of the liver and esophageal varices. N Engl J Med 317: 856-861, 1987.

28. The Committee of Japan Diabetes Society on the diagnostic criteria of diabetes mellitus: Report of the committee on the classification and diagnostic criteria of diabetes mellitus. J Japan Diab Soc 53: 450-467, 2010 (In Japanese).

29. Fujiyama A, Miyanohara A, Nozaki C, Yoneyama T, Ohtomo N and Matsubara K: Cloning and structural analyses of hepatitis B virus DNAs, subtype adr. Nucleic Acids Res 11: 4601-4610, 1983.

30. Firth D: Bias reduction of maximum likelihood estimates. Biometrika 80: 27-38, 1993. 
31. Otsuka M, Uchida Y, Kawaguchi T, et al: Fish to meat intake ratio and cooking oils are associated with hepatitis $C$ virus carriers with persistently normal alanine aminotransferase levels. Hepatol Res 42: 982-989, 2012.

32. Taniguchi E, Kawaguchi T, Sakata M, Itou M, Oriishi T and Sata M: Lipid profile is associated with the incidence of cognitive dysfunction in viral cirrhotic patients: a data-mining analysis. Hepatol Res 43: 418-424, 2013.

33. Adachi S, Shibuya A, Miura Y, Takeuchi A, Nakazawa T and Saigenji K: Impact of occult hepatitis B virus infection and prior hepatitis B virus infection on development of hepatocellular carcinoma in patients with liver cirrhosis due to hepatitis $C$ virus. Scand J Gastroenterol 43: 849-856, 2008.

34. Kao JH, Chen PJ, Lai MY and Chen DS: Occult hepatitis B virus infection and clinical outcomes of patients with chronic hepatitis C. J Clin Microbiol 40: 4068-4071, 2002.

35. Shintani Y, Yotsuyanagi H, Moriya K, et al: The significance of hepatitis B virus DNA detected in hepatocellular carcinoma of patients with hepatitis C. Cancer 88: 2478-2486, 2000.

36. Lok AS, Everhart JE, Di Bisceglie AM, Kim HY, Hussain M and Morgan TR: Occult and previous hepatitis B virus infection are not associated with hepatocellular carcinoma in United States patients with chronic hepatitis C. Hepatology 54: 434-442, 2011.

37. Tamori A, Nishiguchi S, Kubo S, et al: Possible contribution to hepatocarcinogenesis of $\mathrm{X}$ transcript of hepatitis B virus in Japanese patients with hepatitis C virus. Hepatology 29: 1429-1434, 1999.

38. Kim CM, Koike K, Saito I, Miyamura T and Jay G: HBx gene of hepatitis B virus induces liver cancer in transgenic mice. Nature 351: 317-320, 1991.

39. Koike K, Moriya K, Iino S, et al: High-level expression of hepatitis B virus HBx gene and hepatocarcinogenesis in transgenic mice. Hepatology 19: 810-819, 1994.
40. MacKinney AA Jr: Effect of aging on the peripheral blood lymphocyte count. J Gerontol 33: 213-216, 1978

41. Margolis KL, Rodabough RJ, Thomson CA, Lopez AM and McTiernan A: Prospective study of leukocyte count as a predictor of incident breast, colorectal, endometrial, and lung cancer and mortality in postmenopausal women. Arch Intern Med 167: 1837-1844, 2007.

42. Iida M, Ikeda F, Ninomiya T, et al: White blood cell count and risk of gastric cancer incidence in a general Japanese population: the Hisayama study. Am J Epidemiol 175: 504-510, 2012.

43. Barashi N, Weiss ID, Wald O, et al: Inflammation induced hepatocellular carcinoma is dependent on CCR5. Hepatology: Mar 21, 2013 (Epub ahead of print). doi: 10.1002/hep.26403.

44. Pusterla T, Nèmeth J, Stein I, et al: Receptor for advanced glycation endproducts (RAGE) is a key regulator of oval cell activation and inflammation-associated liver carcinogenesis in mice. Hepatology 8: 363-373 2013.

45. Lee FY, Lee SD, Tsai YT, Wu JC, Lai KH and Lo KJ: Serum C-reactive protein as a serum marker for the diagnosis of hepatocellular carcinoma. Cancer 63: 1567-1571, 1989.

46. Dufour JF: C-reactive protein, a prognostic marker in HCC. Hepatology 57: 2103-2105, 2013.

47. Assar S, Arababadi MK, Ahmadabadi BN, Salehi M and Kennedy D: Occult hepatitis B virus (HBV) infection: a global challenge for medicine. Clin Lab 58: 1225-1230, 2012.

48. Matsuoka S, Nirei K, Tamura A, et al: Influence of occult hepatitis $B$ virus coinfection on the incidence of fibrosis and hepatocellular carcinoma in chronic hepatitis C. Intervirology 51: 352-361, 2008. 